DOI 10.5862/JEST.249.14

УДК 621.85

S.I. Hoodorozhkov

\title{
THE MECHANICAL STEPLESS IMPULSE TYPE TRANSMISSION FOR ADVANCED SMALL-SIZED TRANSPORT
}

С.И. Худорожков

\section{МЕХАНИЧЕСКАЯ БЕССТУПЕНЧАТАЯ ИМПУЛЬСНАЯ ПЕРЕДАЧА ДЛЯ СОВРЕМЕННОЙ МАЛОГАБАРИТНОЙ ТРАНСПОРТНОЙ ТЕХНИКИ}

\begin{abstract}
An alternative option of mechanical stepless impulse type transmission for small-sized transport is considered in this paper. The proposed self-regulating automatic stepless transmission allows to significantly improve the technical characteristics of modern CVTs- with respect to power and kinematic ranges as well as design simplicity. In this investigation, the theoretical analysis findings of the operating processes- dynamics and kinematics in impulse transmission are presented for the ATV case in the MATLab - Simulink visual programming environment. It also contains the project efficiency assessment. The results showed that the proposed scheme of mechanical stepless transmission of impulse type has the property of velocity ratio self-regulation. The transmission provides the vehicle's smooth acceleration and uniform motion, without the center differential required. At each wheel's slipping a tractive effort will be transmitted up to the traction limit. As a result the wheel lock is not required in order to improve traction properties. The design of mechanical stepless transmission of impulse type is significantly simpler and cheaper than that of the existing automatic transmissions, it has smaller internal power loss and high application potential in small-sized vehicles.
\end{abstract}

MECHANICAL STEPLESS TRANSMISSION; IMPULSE TRANSMISSION; CVT; SMALL-SIZED TRANSPORT; SIMULATION; MATLAB; SIMSCAPE; DYNAMICS; OPERATING PROCEDURE; ACCELERATION CHARACTERISTIC.

Рассмотрен альтернативный вариант механической бесступенчатой передачи импульсного типа применительно к современной малогабаритной транспортной технике. Предлагаемая саморегулируемая автоматическая бесступенчатая передача позволяет существенно улучшить технические характеристики трансмиссий, выполненных по технологии CVT, в части силового и кинематического диапазонов, а также упрощает конструкцию. Представлены результаты анализа в среде визуального программирования MATLab - Simulink кинематики и динамики paбочих процессов в импульсной трансмиссии на примере мотовездехода, а также дана оценка эффективности ее применения. Показано, что предложенная схема простейшей механической бесступенчатой передачи импульсного типа обладает свойством саморегулирования передаточного отношения.Передача обеспечивает плавный разгон и равномерное движение транспортного средства.Применение межосевого дифференциала не требуется. При буксовании каждое колесо будет передавать тяговое усилие вплоть до предельного по сцеплению.При этом блокировки колес для повышения тяговых свойств не требуется.Предлагаемая конструкция значительно проще и дешевле существующих конструкций автоматических трансмиссий, имеет меньшие внутренние потери мощности и высокий потенциал применения в малогабаритной транспортной технике.

МЕХАНИЧЕСКАЯ БЕССТУПЕНЧАТАЯ ПЕРЕДАЧА; ИМПУЛЬСНАЯ ТРАНСМИССИЯ; СVТ; МОТОТРАНСПОРТНАЯ ТЕХНИКА; МОДЕЛИРОВАНИЕ; МАТLАВ; SIMSСАРЕ; ДИНАМИКА; РАБОЧИЕ ПРОЦЕССЫ; ХАРАКТЕРИСТИКИ РАЗГОНА. 
Advanced motor transport is a huge segment of small-sized vehicles, which includes motorcycles, scooters, mopeds, ATV, snowmobiles, jet skis and other equipment. These vehicles manufactured by famous brands, have been steadily improved, their variety and innovative design being amazing. In recent years motobikes, ATV, snowmobiles have been in increasing demand. ATV (All Terrain Vehicle) and UTV (Utility Task Vehicle) are vehicles intended for traveling and cargo transportation in cross-country conditions, not accessible for conventional cars or motorcycles.

High cross-country capability and maneuverability of such vehicles is provided by application of advanced chassis components and mechanical continuously variable transmission (CVT) with automatic control (Duramatic type, [1]). The latter normally consist of a clutch and an electronically controlled CVT V-belt, which provides stepless torque transmission from the engine to the driving wheels depending on traffic conditions.

The disadvantages of vehicles with CVT are also well known:

1. Narrow range of torque transformation and necessity of additional speed gearbox application.

2. Intensive deterioration of tires and reduction of their service life in full lock of power drive $(4 \times 4)$ that is caused by parasitic power circulation (without the interaxle differential).

3. Unavailability of a self-regulation gear ratio (load-depending) and the necessity of a CVT electronic control system that does not fully satisfy the working conditions.

4. Limited use of this type vehicles by domestic motorists due to high cost of imported equipment.

The novelty of the presented engineering project is that it provides theoretical basis for efficiency of alternative stepless self-regulated impulse transmission (instead of CVT [2]) for small-sized vehicles. There are various designs of mechanical impulse transmissions $[3,4,5,6]$. They are based on conversion of the drive shaft rotation into angular oscillation of the intermediate link, amplitude of these oscillations changing automatically or manually at loading change on the driven shaft. Then angular oscillations of the intermediate link are transformed into unidirectional rotation of the driven shaft by means of a free wheeling clutch (FWC), the greater the oscillations amplitude of the intermediate link the greater the driven shaft velocity.

Application of impulse transmissions for vehicles increases their efficiency, namely:

an additional speed gearbox is not required due to a wider range of torque transformation;

manoeuvrability and cross-country capability are increased due to internal automaticity (self-regulation of gear ratio);

the permanent wheel drive without circulation of parasitic power with automatic compensation of kinematic discrepancy is provided;

transmission is simplified and reduced in cost by eliminating the use of imported components and application of a simple design implemented at an accessible technological level;

maximum efficiency is ensured due to the replacement of the friction variator (CVT) and torque transmission by self-braking friction in FWC instead of friction-slip like in CVT.

Analysis shows that in order to raise technical and economic efficiency of modern small-sized vehicles it would be advisable to use simple self-regulating mechanical stepless transmissions, having a compact, simple design and low cost. According to the published evidence $[4,7,8,9,10]$ it is known that gear ratio changes in impulse transmission can be achieved not only by changing the oscillations amplitude but also due to the links elastic deformation, for example that of the torsion shaft, connected with the FWC. Such engineering solution simplifies the design of impulse transmission and allows to arrange the parts of transmission in overall dimensions of the existing CVT (Duramatic).

This study is aimed at the investigation of vehicle dynamic characteristics with such transmission, namely joint operation of the engine, clutch and stepless impulse transmission during acceleration and uniform motion. An example of the kinematics of an elementary impulse type transmission for all-wheel drive (ATV) is shown in fig. 1.

At the heart of such transmission is the principle of the gear ratio regulation in response of to load changes by automatically changing the swirl angle of torsion shafts 6 connecting the driven links of FWC 5 with the output shafts 7 . 


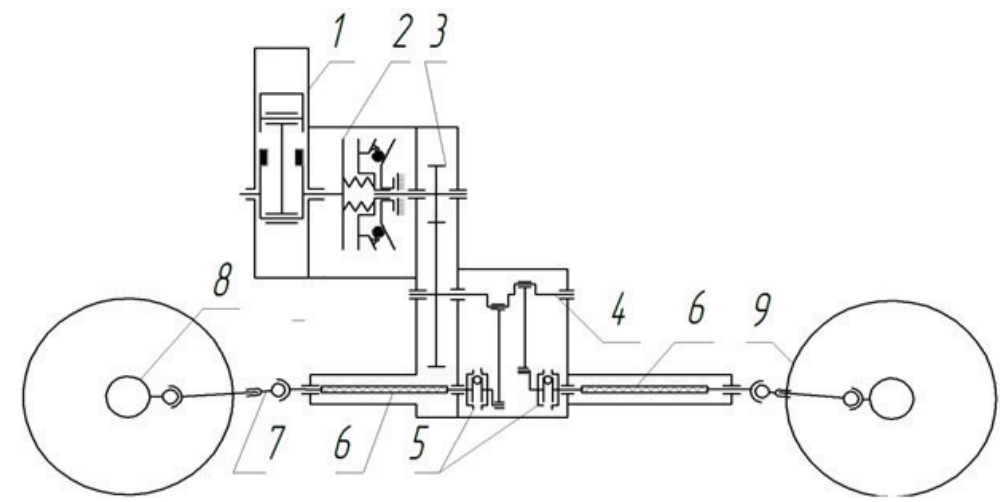

Fig. 1 The kinematics of an elementary impulse type transmission for all-wheel drive (ATV): 1 - engine; 2 - automatic centrifugal clutch;

3 - reducer; 4 - hinged-lever mechanism (generator of mechanical oscillations); 5 - free wheeling clutch (FWC); 6-torsion shaft; 7 - cardan drive; 8 - differential; 9 - driving wheels.

Transmission operates as follows. The rotation from the engine 1 , the centrifugal clutch 2 and the reducer 3 with angular velocity $\omega$ is transmitted to the hinged-lever mechanism 4, generating angular oscillations of the FWC driving parts 5 with constant amplitude $\varphi_{0}$. In case of harmonic oscillations its angular speed is equal to

$$
\omega_{1}=\varphi_{0} \omega \sin (\omega t) \text {. }
$$

If there is no resisting torque on the driving wheels 9 (theoretically), the torsion shafts 6 , connected through the cardan drives 7 and differentials 8 with the drive wheels 9 , are not loaded by torque. Their swirl angles for a cycle oscillation are theoretically equal to zero, while gear ratio due the torsion shaft deformation $6 i=1$. If angular velocity of the driving wheels 9 and cardan drive 7 becomes smaller by resisting torque, the swirl angles of the torsion shafts vary proportionally to the load; in case of maximum deformation of the torsion shaft 6 in the "stale condition", the internal gear ratio will be equal to $i=0$. In operating procedure, the smaller gear ratio $i$, the earlier FWC 5 is switched on and later switched off, and the greater are maximum and average swirl angles of torsion shafts 6 , as well as the average torque transmitted to the driving wheels 9. In this case, torque transmission from the engine 1 through FWC 5 to the front and rear axles is carried out with a phase lag 180 deg.

The clutch 2 is used for smooth breakaway and acceleration with a necessary intensity. The reducer 3 is required to lower the engine speed with a view to decreasing the frequency of FWC engaging. Reverse motion at this scheme, is provided by the FWC reverse operation [11, 12] (not shown). The procedure of determination of ATV tractive-dynamic characteristics and the simulation results are presented below.

Initial data:

Gross vehicle weight $-550 \mathrm{~kg}$; maximum speed $-80 \mathrm{~km} / \mathrm{h}$; engine capacity - $38 \mathrm{~kW}$; type of drivingwheels - AT25h8-12 (26h8-14); wheel arrangement $-4 \times 4$; traffic conditions: coefficient of motion resistance $f=0,015$, and traction coefficient of $\mu=0,65$, without considering the wind load; upgrading - at least 25 degrees.

The operating procedures simulation of the mechanical impuls transmission was performed in MATLAB-SIMULINK $[13,14]$. The block diagram of power train consisting of several subsystems is shown in fig. 2 .

Inertial properties of the rotating shafts and gears are taken into account by means of the "Inertia" blocks. The inertial properties of the engine, clutches, driving wheels and ATV chassis options are embedded in the parameters of the relevant subsystems. Sensors of angular velocity and torque, as well as the signal receivers are not shown.

SIMULINK block diagram is made up of several subsystems.

1. Subsystem 1 - "Engine", includes:

block «Engine» from the Simulink library «Simscape - SimDriveline» with the following parameters: the engine type - petrol, the maximum power $50 \mathrm{hp}$, the maximum speed $-6500 \mathrm{rev} / \mathrm{min}$; inertia $-0,1 \mathrm{~kg} \cdot \mathrm{m}^{2}$; Engine power speed characteristic is approximated by a polynomial of the third degree;

block «Signal Builder / Throttle» [15], determining the engine fuel supply. 

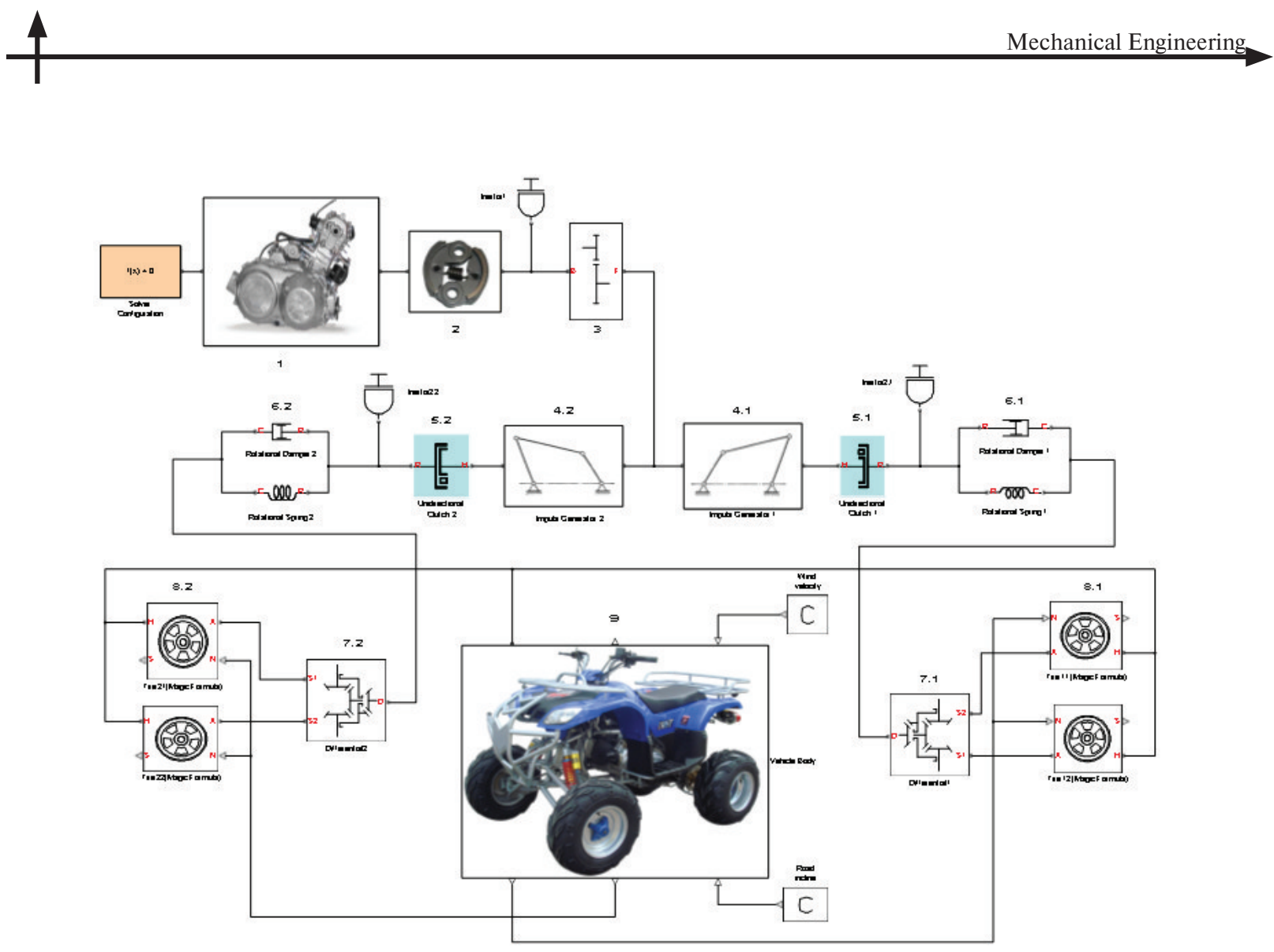

Fig. 2. SIMULINK block diagram of the ATV with simplest stepless mechanical impuls transmission Here: 1 - engine; 2 - clutch; 3 - reducer; 4.1 and 4.2-generators of mechanical oscillations in the front and rear power circuit, respectively; 5.1 and 5.2 - free wheeling clutches; 6.1 and $6.2-$ torsion shafts (taking into account hysteresis losses); 7.1 and 7.2 - cross-axle differentials in the front and rear axles; 8.1 and $8.2-$ driving wheels of the front and rear axles; $9-$ ATV body

2. Subsystem 2 - "Clutch" includes:

block «Disk Friction Clutch» from the Simulink library «Simscape - SimDriveline» with the following parameters: the type - disk, the effective radius of the friction discs $-60 \mathrm{~mm}$; the discs number -2 ; the clutch type - hydraulic; the piston actuator cylinder area $-0,005 \mathrm{~m}^{2}$; friction coefficient (static / dynamic) $-0,7 / 0,55$;

block «Signal Builder/Pressure» determining the acceleration rate in clutch switching.

3. Inertia of rotating masses - «Inertia» blocks from Simulink library «Simscape - Mechanical Rotational Elements» - on transmission inlet «Inertia1» and on the FWC outlet «Inertia2.1» and «Inertia2.2 are equal respectively 0,5 and $0,0001 \mathrm{~kg} \cdot \mathrm{m}^{2}$.

4. Reducer (3) - a standard bloc «Simple Gear» from Simulink library «Simulink - Simscape - SimDriveline - Gears» with a ratio equal to 3 .

5. Hinged-lever mechanisms «Impuls Generator» (4.1 and 4.2) form mechanical harmonic oscillations with a constant amplitude $\varphi_{0}=0,35 \mathrm{rad}$ in two power flows (front and rear axles) with a phase lag 180 degrees.
6. FWC «Unidirectional Clutch» (5.1 and 5.2) converts harmonic oscillations into unidirectional motion of torsion shafts - block of Simulink library «Simscape - SimDriveline - Clutches».

7. Torsion shafts «Torsional Spring - Damper» (6.1 and 6.2) - block from Simulink library «Simscape - SimDriveline - Couplings \& Drives». They have the following parameters: angular stiffness of $2100 \mathrm{~N} \cdot \mathrm{m} / \mathrm{rad}$, damping coefficient of $0,01 \mathrm{~N} \cdot \mathrm{m}$ / $(\mathrm{rad} / \mathrm{sec})$.

8. The cross-axle differential mechanisms 7.1 and 7.2 «ifferential» - distributes torque to the driving wheels of the front and rear axles with a ratio of 0,7 . Blocks from a library «Simulink - Simscape - SimDriveline - Gears».

9. The driving wheels 8.1 and $8.2-$ form a longitudinal traction force proportional to the weight and traction coefficient. The wheels radius is $0,32 \mathrm{~m}$, the load on the wheel in a static position is uniform. Longitudinal linear stiffness of the tires $-1000 \mathrm{kN} / \mathrm{m}$; longitudinal tire damping coefficient $-1000 \mathrm{~N} /$ $(\mathrm{m} / \mathrm{s})$; inertia $-0,5 \mathrm{~kg} \cdot \mathrm{m}^{2}$. 
10. Subsystem $9-$ - Vehicle body», includes:

«Vehicle body» block from the library «Simscape - SimDriveline - Tires \& Vehicles» with parameters: mass $-550 \mathrm{~kg}$; number of wheels per axle -2 ; front area $-1,5 \mathrm{~m}^{2}$; drag coefficient $-0,4$; mass center coordinates - 0,6/0,6/0,5 m.

The total efficiency of the mechanical power train (including losses in the gearing, differentials, bearings and others) is assumed equal to $\eta=0,92$.

The simulation results of the stepless transmission>s operation parameters in accelerating from stop to maximum speed are shown in fig. 3-6.

At the initial starting point (smooth clutch switching and the fuel feed increasing) the engine torque is transmitted through the reducer 3 to the second intermediate shaft. Next, by means of unregulated hinged-lever mechanisms 4.1 and 4.2 the rotation is converted into the angular oscillations of FWC leading links 5.1 and 5.2 with phase bias 180 degrees (fig. 3).

Two FWC (one for each axle) transmit torque only in one direction. Idle running is carried out in the other direction. Therefore, they convert the angular oscillations into unidirectional rotation, that is transmitted by means of the torsion shafts $6.1,6.2$ and cross-axle differentials 7.1 and 7.2 to the front and rear driving wheels.

The larger the oscillation amplitude, the higher rotation speed of the driving wheels. In this case the wheel's speed changes automatically according to the resistance movement at constant of FWC oscillation amplitude.

If the resistance on driving wheels is great (acceleration start) and they rotate at a low speed, the main part of the FWC cycle is switched on, its driven links oscillate together with the driving links and only a small portion of the FWC cycle is switched off. This is accompanied by the appearance of free oscillations of the driven links - splined end of the torsion shaft (see fig. 4, $a$ ).
It is important to observe that frequency of natural oscillations of the torsion shaft with the driven links of FWC is much higher than oscillation frequency generated by the hinged-lever mechanisms. This is a prerequisite that must be provided by the design, because transmission can work only below resonance band.

If resistance at the driving wheels is small (at the acceleration end), the oscillations of FWC driven links of are very close to the maximum value of the angular velocity of the driving links (fig. 4,b), the torsion shaft twisting is reduced. Inertia of transmission's driven parts is sufficiently large, therefore angular velocity reduction during one cycle (one revolution driving shaft) is immaterial.

Swirl angles of torsion shafts per cycle vary from zero up to a maximum value equal to twice the oscillations amplitude of the FWC driving links (fig. 5, $a, b$ ).

If resistance on the driving wheels is smaller than torque from the swirl angle of the torsion shaft, the wheels are driven, if otherwise, the wheels are in the "stale condition" (with the fired engine). The average torsion shaft's swirl angle is equal to the oscillations' amplitude of the FWC's driving links, and the average torque on the driving wheels is equal to the average twist angle multiplied by the angular stiffness of the torsion shaft and the gear ratio of the wheel differential.

The maximum torsion swirl angle is reduced from 24 to 10 degrees, with ATV increasing speed (fig 5, $a, b)$. The decreasing deformation of the torsion shafts occurs automatically and is proportional to the vehicle's acceleration reduction, being determined by the engine's excess capacity over the resistance power.

Fragments of operating curves of transmission - the input torque (links 4.1 and 4.2, fig. 2) and output torque (links 7.1 and 7.2 ) in timing are shown in fig. $6, a$. 
Angular speed, $\mathrm{rad} / \mathrm{sec}$.

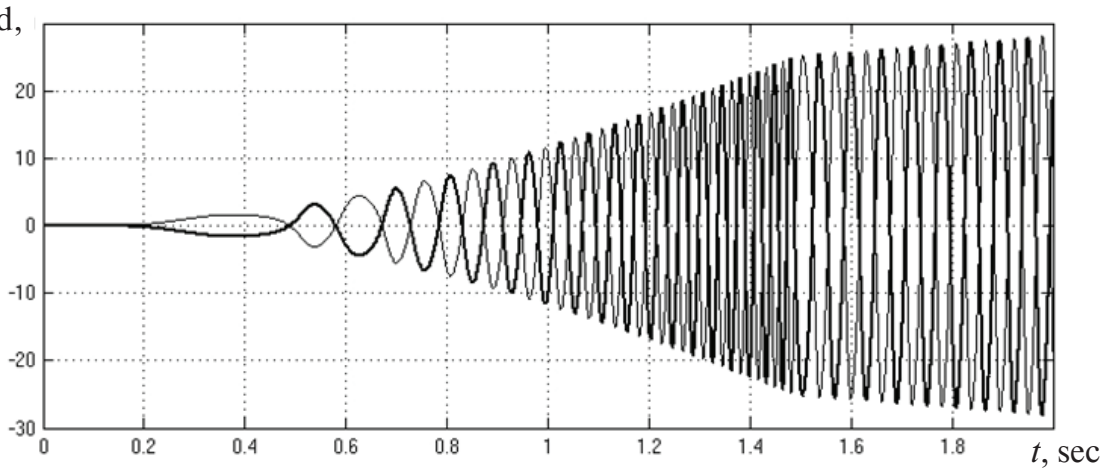

Fig. 3. Angular speed (rad/sec) of the FWC driving links formed by mechanical oscillations generator in the acceleration initial period in the interval from 0 to 2 seconds

a) Angular velocity, $\mathrm{rad} / \mathrm{sec}$.

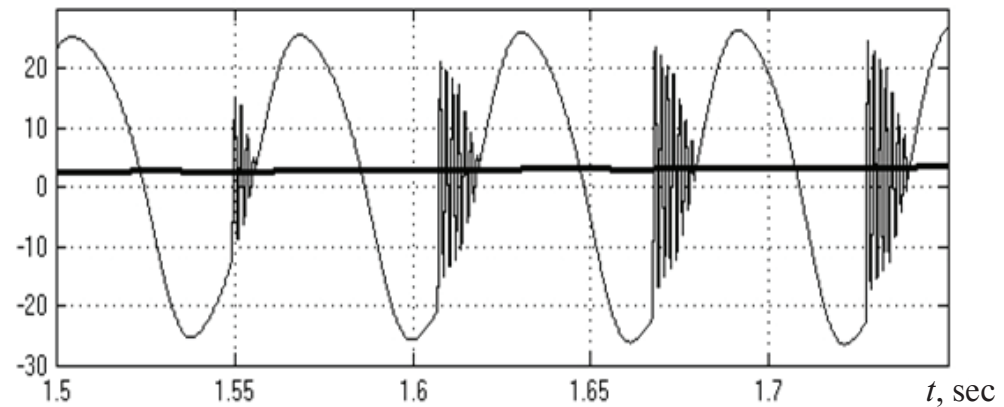

b) Angular velocity, $\mathrm{rad} / \mathrm{sec}$.

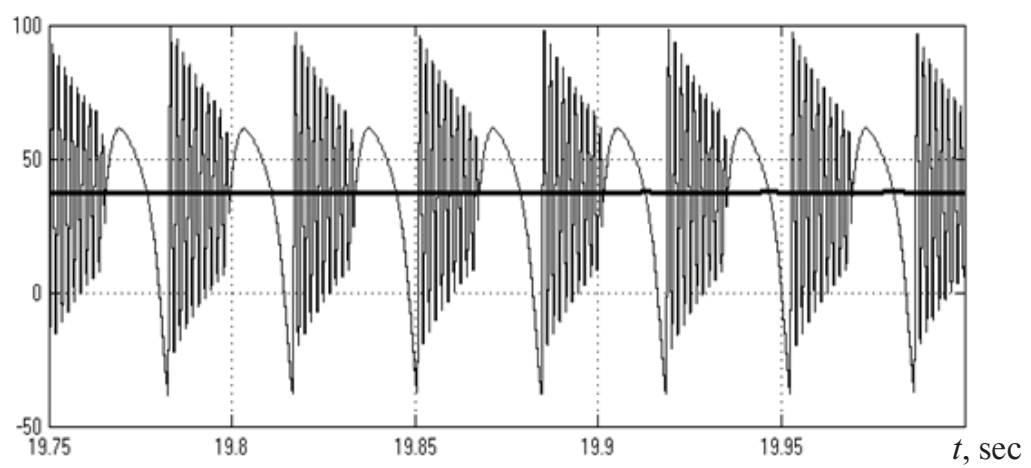

Fig. 4. Angular velocity (rad/s) of driving and driven ends of torsion shaft: $a$ ) at the acceleration start for a period of 0,25 seconds (from 1,5 to $1,75 \mathrm{sec}$.); $b$ ) at the acceleration end for a period of 0,25 seconds (from 19,75 to $20,0 \mathrm{sec}$.) 
a) Cyclic angle deformation, degr.

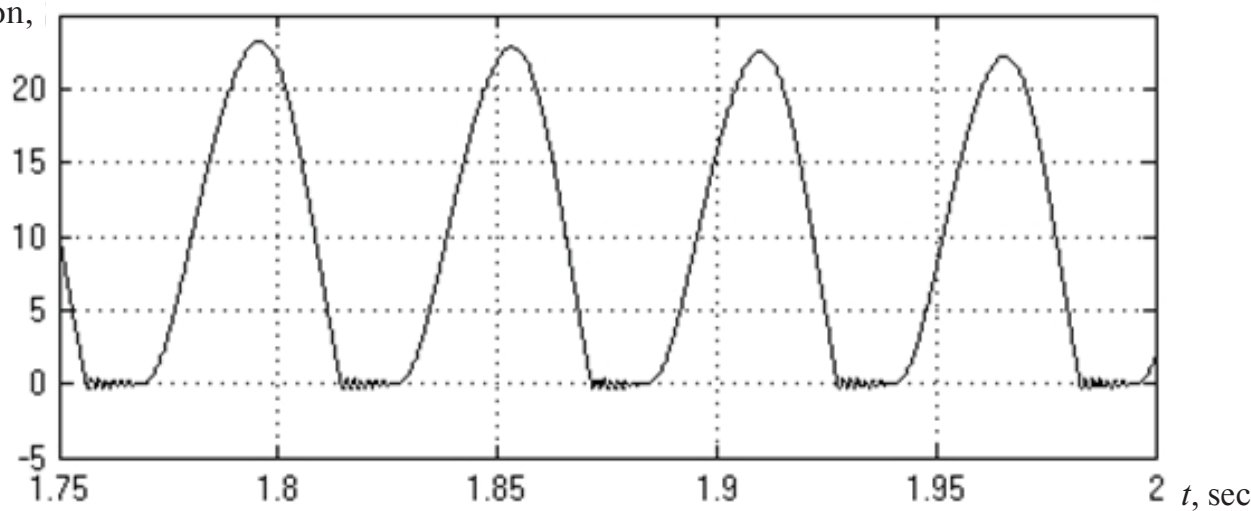

b) Cyclic angle deformation, degr.

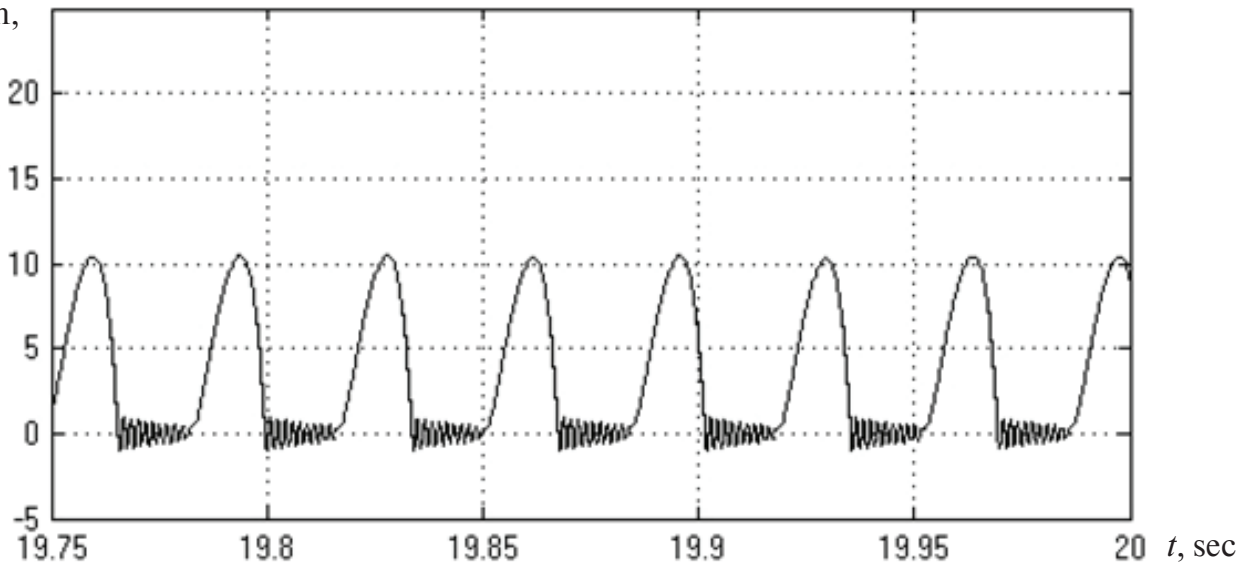

Fig. 5. Cyclic angle deformation (degrees) of the torsion shaft: $a$ ) at the acceleration start for a period of 0,25 seconds (from 1,5 to $1,75 \mathrm{sec}$.); $b$ ) at the of acceleration end for a period of 0,25 seconds (from 19,75 to 20,0 sec.) 
a)

Torque, $\mathrm{Nm}$

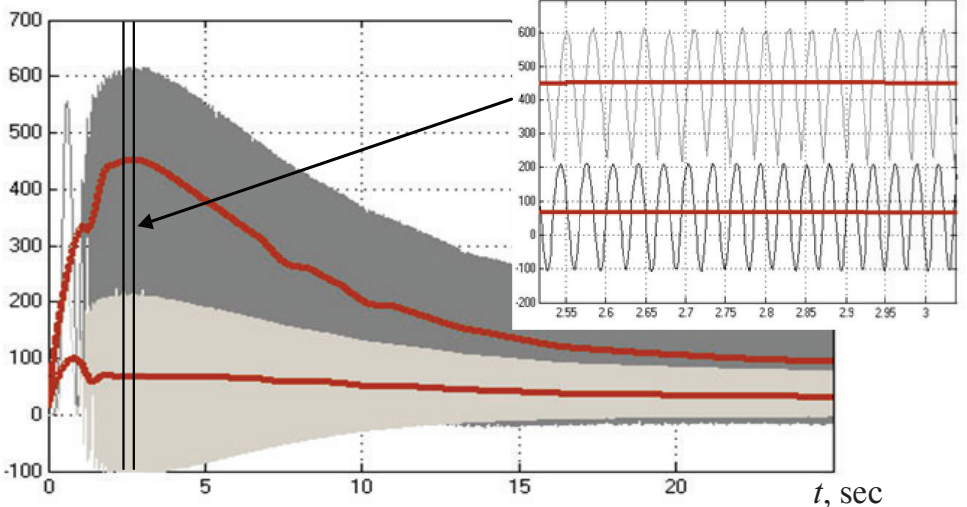

b) Tractive effort, $\mathrm{Nm}$

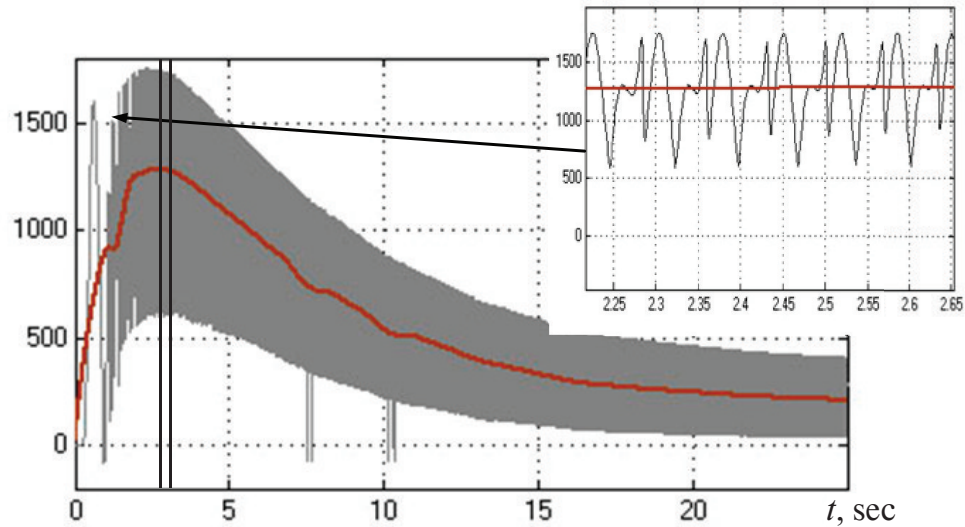

c)

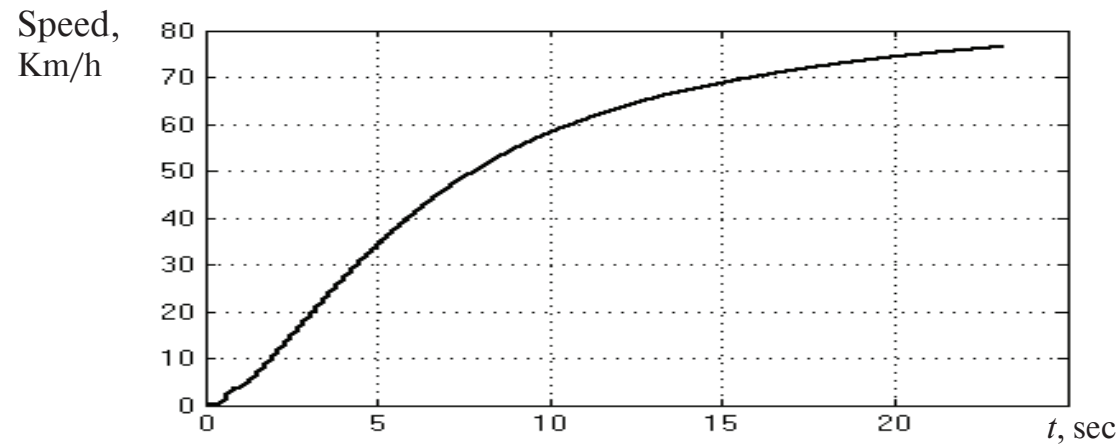

Fig. 6. Dynamic parameters of ATV acceleration: $a$ - momentary and average torque values $(\mathrm{N} \cdot \mathrm{m})$ at the input (white background, black curve) and aggregate momentary and average torque values on output shaft of impulse transmission (dark background, the black curve) in the time interval from 0 to 25 seconds; $b$ - change of total momentary and average tractive effort (N) of driving wheels (light background, black curve) in the time interval from 0 to 25 seconds; $c$ - change of ATV >s speed $(\mathrm{km} / \mathrm{h})$ in the time interval from 0 to 25 seconds

The transmission power range $d$ (output to input torque ratio) is:

$$
d=\frac{\operatorname{mean}\left[(2 \cdot \mathrm{M} 81+2 \cdot \mathrm{M} 82)_{\max }\right]}{\operatorname{mean}\left(\mathrm{M} 3_{\max }\right)}=\frac{400}{65}=6,2
$$

that exceeds the torque transformation range of the existing continuously variable transmissions. Here the subscript «max» means the maximum average value of torque over the whole range of gear ratios. 
An additional advantage of impulse transmission is that it allows to work a long time in so-called "stale condition" (driving wheels stop when transmitting torque from the engine) and has at the same time the theoretical transformation ratio $\mathrm{K}$, equal to infinity. Real $\mathrm{K}$ factor has a finite value, because there are hysteresis losses in loading-unloading cycles, but these losses are negligible.

Total traction's changes $(\mathrm{N})$ of the ATV's driving axles during the acceleration are shown in fig. $6, b$. Maximum oscillation amplitude of the total tractive force amounts to $600 \mathrm{H}$ with an average of $1200 \mathrm{~N}$ and is implemented at the acceleration start, then traction gradually declines. The oscillations amplitude of the total tractive force at the acceleration end is about of $150 \mathrm{~N}$ with an average of $250 \mathrm{~N}$.

The oscillation amplitude of the intermediate links' torque (at a frequency of 10 to $30 \mathrm{cycles} / \mathrm{sec}$ ) and driving wheels traction $(20-60$ cycles/sec) is filtered and provides ATV smooth acceleration and uniform motion (fig. 6,c) due to the vehicle inertia and the chassis damping properties. The graph shows that the ATV accelerates smoothly to a speed of about $80 \mathrm{~km} / \mathrm{h}$ in 25 seconds. The driving wheels' slip at constant engine speeds is of the order $1 \%$.

As a result of the performed theoretical study it was determined:

1. The proposed scheme of simple mechanical stepless transmission of impulse type has the prop- erty of self-regulation control. Thus, for the period of ATV acceleration from a standstill to $80 \mathrm{~km} /$ hour with an increase in the engine's angular velocity from 75 to $600 \mathrm{rad} / \mathrm{sec}$, the average angle of the torsion shafts' twist has changed from 15 degrees in the initial phase up 5 degrees - at the end, i.e. transformation ratio is 3 . At the same time, taking into account the engine acceleration and tire traction the total average tractive force of the driving wheels has changed from 400 to $100 \mathrm{~N}$. This transmission provides the ATV's smooth acceleration and uniform motion.

2. The FWC driven links are not connected to each other kinematically, and therefore, the power to the driving wheels of the front and rear axles is transmitted independently in accordance with the elastic characteristic of the torsion shafts, i.e. the driving wheels can rotate with different angular velocities; the torques transmitted to the driving axles are determined by elastic characteristics of their own torsion shaft. Application of the center differential is not required. When wheels of one driving axle slip, the other driving axle will transmit tractive force up to the traction limits. Therefore, the central differential locking in order to improve traction properties of the driving wheels is not required.

3. The design_of the self-regulating mechanical impulse transmission is significantly simpler and cheaper than available automatic transmissions, it has less internal power loss and a high application potential in small-sized vehicles [16].

\section{REFERENCES}

1. POLARIS. The Way Out. 2003 ATV. Universal Owner's Manual for Vehicle Maintenance and Safety // Polaris Industries Inc. Copyright 2002. P. 153.

2. Arctic Cat Service Manual for the 2012 Arc- tic Cat XC 450i ATV // Product Service and Warranty Department Arctic Cat Inc. Copyright 2011. P. 123.

3. George Constantinesco. Inertial Transmission. http://www.rexresearch.som/constran/lconstran.htm.

4. Blagonravov A.A. The mechanical continuously variable transmission / Ural Branch of Russian Academy of Sciences. Ekaterinburg, 2004. P. 203-204.

5. Blagonravov A.A., Hoodorozhkov S.I. Dynamics of the mechanical continuously variable transmission [The dynamics of the mechanical continuously variable transmission]. Problems of mechanical engineering and reliability, 2002. 6. P. 19-24.

6. The patent of Russia №2252351. The mechanical self-regulating continuously variable transmission / Hoodorozhkov S.I.

7. Blagonravov A.A., Hoodorozhkov S.I. Dynamic behavior of the self-regulating mechanical continu- ously variable transmission. Materials of the All-Russian scientific-practical conference "Reducer's building of Russia: state, problems and opportunity». St. Petersburg, 2003. P. 192-194.

8. Blagonravov A.A., Revnyakov Ye.N. The mechanical continuously variable impulse type transmission. $\mathrm{Mo}$ tor-car industry. 2007. № 5. P. 11-14.

9. Hoodorozhkov S.I. Simulation of the impulse transmission's dynamics with an elastic linkage. Interuniversity collection of learned works «The continuously variable transmissions and freewheel mechanisms».Kaliningrad, 2001. P. 142-148.

10. Blagonravov A.A., Hoodorozhkov S.I. External characteristic of the multithreaded continuously variable transmission with elastic linkages. Collection of Short Message "XXII Russian School on Science and Technology». Yekaterinburg, 2002. P. 82-84.

11. Lester W.T. Infinitely Variable Transmission Utilizing Oscillating Torque. http://ebookbrowse.com/infinitely-variable-transmission-utilizing-oscillating-torquedoc-d420263879. 
12. The patent of Russia №2373441. Free-wheel clutch mechanism / Hudorozhkov S.I.

13. Hudorozhkov S.I. Theory and automatic control systems. Analysis and synthesis of transport systems in Simulink environment: tutorial. SPb: Publishing house of the Polytechnic University Press, 2014. 110 p.

14. Hudorozhkov S.I. Theory and automatic control system. Design of automatic control system performance in Simulink environment: tutorial. SPb: Publishing house of the Polytechnic University Press, 2014. 53 p.
15. Hudorozhkov S.I. Theory and automatic control system. Analysis and synthesis in Simulink environment. Standard blocks' library: tutorial. SPb: Publishing house of the Polytechnic University Press, 2013. 90 p.

16. Khudorozhkov S.I., Galyshev Yu.V. Dinamika rekuperativnogo mekhanicheskogo besstupenchatogo privoda transportnogo sredstva. Nauchno-tekhnicheskiye vedomosti SPbPU / [St.Petersburg Polytechnic University Journal of Engineering Sciences And Technology]. 2013. № 3 (178). S. 216-222. (rus.)

\section{СПИСОК ЛИТЕРАТУРЫ}

1. POLARIS. The Way Out. 2003 ATV. Universal Owner's Manual for Vehicle Maintenance and Safety // Polaris Industries Inc. Copyright 2002.P.153

2. Arctic Cat Service Manual for the 2012 Arc- tic Cat XC 450i ATV // Product Service and Warranty Department Arctic Cat Inc. Copyright 2011. P. 123.

3. George Constantinesco: Inertial Transmission, http://www.rexresearch.com /constran/1constran.htm.

4. Благонравов А.А. Механические бесступенчатые передачи УрО РАН. Екатеринбург, 2004. 203 с.

5. Благонравов А.А., Худорожков С.И. Динамика механической бесступенчатой передачи // Проблемы машиностроения и надежности машин. 2002. № 6. С. 19-24.

6. Патент РФ №2252351. Механическая саморегулируемая бесступенчатая передача / С.И. Худорожков. Приоритет 20.05.2005.

7. Благонравов А.А., Худорожков С.И. Динамическая характеристика саморегулируемой механической бесступенчатой передачи // Материалы Всероссийской научно-практической конференции «Редукторостроение России: состояние, проблемы, перспективы». СПб, 2003. С. 192-194.

8. Благонравов А.А., Ревняков Е.Н. Механическая бесступенчатая передача импульсного типа // Автомобильная промышленность. 2007. № 5. С. 11-14.

9. Худорожков С.И. Компьютерное моделирование динамики импульсной передачи с упругим звеном // Межвузовский сборник научных трудов
«Бесступенчатые передачи и механизмы свободного хода». Калининград, 2001. С.1 42-148.

10. Благонравов А.А., Худорожков С.И. Внешняя характеристика многопоточной бесступенчатой передачи с упругими звеньями // Сборник кратких сообщений «XXII Российская школа по проблемам науки и технологий». Екатеринбург, 2002. С. 82-84.

11. Lester W. T., Infinitely Variable Transmission Utilizing Oscillating Torque // http://ebookbrowse.com/ infinitely-variable-transmission-utilizing-oscillatingtorque-doc-d420263879.

12. Патент РФ №2373441. Механизм свободного хода / С.И. Худорожков. Приоритет 20.11.2009.

13. Худорожков С.И. Теория и системы автоматического управления. Анализ и синтез САУ транспортных систем в среде Simulink: учеб. пособие. СПб.: Изд-во Политехн. ун-та, 2014. 110 с.

14. Худорожков С.И. Теория и системы автоматического управления. Построение характеристик САУ в среде Simulink: Учеб. пособие. СПб.: Изд-во Политехн. ун-та, 2014. 53 с.

15. Худорожков С.И. Теория и системы автоматического управления. Анализ и синтез в среде Simulink. Библиотека стандартных блоков: Учеб. пособие. СПб.: Изд-во Политехн. ун-та, 2013. 90 с.

16. Худорожков С.И., Галышев Ю.В. Динамика рекуперативного механического бесступенчатого привода транспортного средства // Научно-технические ведомости СПбПУ. 2013. № 3 (178). С. 216-222.

\section{СВЕДЕНИЯ ОБ АВТОРAX/AUTHORS}

HOODOROZHKOV Sergey I. - Peter the Great St. Petersburg Polytechnic University.

29 Politechnicheskaya St., St. Petersburg, 195251, Russia.

E-mail: xcu-55@mail.ru

ХУДОРОЖКОВ Сергей Иванович - доктор технических наук профессор Санкт-Петербургского политехнического университета Петра Великого. 195251, Россия, г. Санкт-Петербург, Политехническая ул., 29.

E-mail: xcu-55@mail.ru 